\title{
Analisis Efisiensi Dan Efektifitas Pengelolaan Dana Desa (Study Empiris Dana Desa di Desa Tegalarum Kabupaten Demak Tahun 2016-2020)
}

\author{
${ }^{1}$ Ali Khadlirin , ${ }^{2}$ Edy Mulyantomo, ${ }^{3}$ Sri Yuni Widowati \\ ${ }^{1}$ S1 Manajemen FE, Universitas Semarang,Semarang, Indonesia \\ ${ }^{2}$.S1 Manajemen FE, Universitas Semarang, Semarang, Indonesia
}

\section{INFO ARTIKEL}

Proses Artikel

Dikirim :

Diterima:

Dipublikasikan:April 2021

\begin{abstract}
ABSTRAK
Penelitian ini bertujuan untuk menganalisis tingkat efisiensi dan efektivitas pengolahan Dana Desa di Desa Tegalarum, Kecamatan Mranggen Kabupaten Demak. Alat analisis yang digunakan dalam penelitian ini adalah metode Kombinasi (Mix Methods), yaitu menganalisis data target, antara realisasi belanja dan pendapatan dengan menggunakan rasio efisiensi dan efektivitas, berdasarkan Keputusan Menteri Dalam Negeri No.690.900-327 tahun 1996 serta melengkapi dengan data wawancara.

Pengambilan data menggunakan model Sequential Explanatory Design, dimana model tersebut bercirikan pengumpulan data dan analisis data kuantitatif pada tahap pertama, dan diikuti dengan pengumpulan dan analisi data kualitatif pada tahap kedua, guna memperkuat hasil penelitian kuantitatif yang dilakukan pada tahap pertama. Penelitian dilakukan di Desa Tegalarum Kecamatan Mranggen Kabupaten Demak. Pemilihan lokasi ditetapkan secara sengaja (purposive), yaitu pengambilan lokasi berdasarkan kriteria yang telah ditentukan.

Hasil penelitian ini menunjukan bahwa tingkat rata-rata efisiensi pengelolaan Dana Desa di Desa Tegalarum Kecamatan Mranggen, Kabupaten Demak sebesar 95,57\% yang memenuhi kriteria efeisien, dan tingkat rata-rata efektivitas sebesar 95,60\%, termasuk dalam kategori efektif.
\end{abstract}

Kata Kunci :

Dana Desa, Efisiensi, Efektivitas, Desa Tegalarum.

\section{PENDAHULUAN}

Latar Belakang

Tujuan didirikan Negara untuk mencapai kesejahteraan bagi seluruh rakyat (UUD 1945). Usaha mencapai tingkat kesejah-teraan, dilakukan dengan berbagai upaya diantaranya adalah penyelengaraan peme-rintahan yang bersih dan akuntabel serta aplikasi pembangunan. Namun, pembangunan nasional yang dilakukan selama ini, hanya memberikan dampak kesenjangan kesejahteran penduduk, di ukur dengan tingkat kemiskinan antara masyarakat perkotaan dan perdesaan menurut BPS (2019) adalah sebagai berikut: 
Tabel 1 Kemiskinan di Indonesia

\begin{tabular}{cc}
\hline Perkotaan & Perdesaan \\
Maret 2019 & Maret 2019 \\
\hline$(\%)$ & $(\%)$ \\
6,69 & 12,85 \\
\hline & Sumber: BPS 2020
\end{tabular}

Pada table 1 terlihat bahwa prosentase penduduk miskin di perkotaan pada bulan maret 2019 sebesar 6,69\% sedangkan di perdesaan sebesar 12,85\%. Tingginya kesenjangan tersebut mendorong pemerintah untuk menerbitkan UU No 06/2014 Tentang Desa, yang intinya desa menjadi otonom dan mandiri, salah satunya melalui pemberian dana desa. Dana desa merupakan legal formal pengakuan dari pemerintah akan keberadaan desa, sehingga desa merupakan satu kesatuan dari system pemerintahan. Konsekuensi logis dari pelaksanaan pemerintahan adalah adanya dana untuk operasional dan pembangunan desa, (Moeljono \& Kusumo, 2019)

Desa Tegalarum Kabupaten Demak, salah satu penerima Dana Desa, mempunyai letak yang startegis. Keberadaannya di perbatasan antara Kabupaten Demak dengan Kota Semarang yang sekaligus sebagai jalur alternative jalur pantura merupakan desa yang terus mengalami perkembangan dibidang pembangunan secara signifikan. Pembangunan yang dilakukan, memerlukan banyak biaya. Salah satu sumber pembiayaannya dari Dana Desa. Dana desa yang diterima seperti tertera pada tabel 2

Tabel 2 Rincian Dana Desa Tegalarum Kabupaten Demak Tahun 2016-2020

\begin{tabular}{crrr}
\hline Tahun & Alokasi Dasar & Pagu Dana Desa & \multicolumn{1}{c}{$\begin{array}{c}\text { Pagu Dana Desa } \\
\text { Pembulatan }\end{array}$} \\
\hline 2016 & 689.881 .000 & 689.881 .000 & 689.881 .000 \\
2017 & $720,442,000.00$ & $880,442,628.93$ & $880,443,000.00$ \\
2018 & $616,345,000.00$ & $1,012,825.488 .00$ & $1,012,825,000.00$ \\
2019 & $672.421 .000,39$ & $1.016 .591,578.00$ & 1.016 .591 .000 .00 \\
2020 & $1.058 .909 .000,00$ & $1.058 .909 .000,00$ & $1.058 .909 .000,00$ \\
\hline \multicolumn{4}{c}{ Sur }
\end{tabular}

Sumber: JDIH Kabupaten Demak (2020)

Pada Tabel 2 terlihat bahwa dana desa yang di terima oleh Pemdes Tegalarum mengalami peningkatan secara terus menerus sampai tahun 2020. Adanya kenaikan ini menunjukan bahwa Pemdes Tegalarum mampu mengelola Dana Desa dengan baik. Hal ini sejalan dengan hasil penelitian Moeljono \& Kusumo, 2019, yang menunjukan bahwa Pengelolaan Dana Desa, di desa Tegalarum Kabupaten Demak pada tahun 2019 yang bertujuan untuk mengetahui Efektifitas Pengelolaan Dana Desa. Efektifitas diukur dari perencanaan, pelaksanaan dan pengawasan. Menunjukan hasil, secara administrasi ketiga tahap tersebut dapat terselesaikan dengan baik dan memenuhi prinsip efektif yang di indikatori adanya tranparansi informasi kepada masyarakat.

Namun hasil penelitian yang dilakukan oleh Wida (2016) menunjukan bahwa pada tahap perencanaan dan pelaksanaan telah sesuai dengan prosedur yang berlaku dan pengelolaannya telah dilakukan secara akuntabel dan transparan. Namun, pada tahap pengawasan belum berjalan dengan baik karena kurangnya transparansi terhadap masyarakat, demikian juga pada tahap pertanggungjawaban belum berjalan dengan baik. Demikian juga hasil penelitian Sulastri (2016), menghasilkan bahwa Efektifitas Pengelolaan Dana Desa dalam meningkatkan pembangunan fisik, dimana tahap perencanaan, pelaksanaan dan pertanggungjawaban. Berdasarkan hasil penelitian, tahapan perencanaan, pelaksanaan dan tahap pertanggungjawaban kurang efektif. Demikian juga penelitian yang dilakukan oleh Mahfud (2009) menyatakan sebagian besar 
penggunaan Dana Desa lebih banyak diarahkan pada kegiatan fisik dan penambahan kesejahteraan perangkat desa dalam bentuk dana purna bakti, tunjangan dan sejenisnya serta sebagian lagi untuk kegiatan rutin. Sementara itu, dari aspek realisasi masih ditemui realisasi DD di bawah 60\%. Kemudian, penelitian Hargono (2010) di Kabupaten Karangasem, Bali menemukan besarnya Dana Desa yang diberikan ke setiap desa tidak menggunakan formula yang ditentukan dengan pembobotan tujuh variabel penting desa, tetapi menggunakan pembagian total jumlah desa di Kabupaten untuk penentuan ADDM (ADD Merata) dan pembagian total jumlah banjar dinas untuk penentuan ADDP (ADD proporsional).

Kajian mengenai dana desa ini merupakan kajian yang baru dan menarik mengingat penyaluran dana desa baru diberlakukan pada tahun 2015. Berdasarkan pertimbangan dan kenyataan di atas, diharapkan keseluruhan Pemdes dapat mengoptimalkan anggaran Dana Desa yang dimiliki sehingga penggunaan Dana Desa ini dapat menggerakkan roda perekonomian desa, maka pembangunan desa akan semakin meningkat. Pembangunan yang meningkat ini diharapkan akan mengurangi disparitas pertumbuhan antar desa.

Perumusan permasalahan dalam penulisan ini adalah proses pengelolaan Dana desa dari awal sampai akhir dan pengaruhnya bagi masyarakat di wilayah Desa Tegalarum, Kabupaten Demak. Pembatasan permasalahan dibatasi pada dua prioritas utama alokasi program Dana Desa yang tercantum pada PP No.60/2014, yaitu untuk pembiayaan pembangunan desa yang meliputi infastruktur dan pemberdayaan masyarakat Desa Tegalarum Kabupaten Demak Periode 20162020.

\section{KAJIAN PUSTAKA}

Neumen (dalam Sugiyono, 2017), teori adalah seperangkat konstruk (konsep), definisi, dan proposisi yang berfungsi untuk melihat fenomena secara sistematik, melalui spesifikasi hubungan antara variabel, sehingga dapat berguna untuk menjelaskan dan meramalkan fenomena. Teori yang perlu dibahas dalam penelitian ini, yaitu penjelasan mengenai Pengelolaan, Dana Desa, Effektifitas dan Effisiensi.

\section{Konsep Pengelolaan Keuangan Desa}

Kata "pengelolaan" indentik dengan manajemen yaitu proses menggerakan, mengorganisasikan, dan mengarahkan usaha untuk memanfaatkan secara efektif material dan fasilitas untuk mencapai suatu tujuan (Balderton dalam Adisasmita, 2011 dan Arikunto, 1993). dalam konsep tersebut Fattah (2004) berpendapat bahwa dalam proses manajemen terlibat fungsi-fungsi pokok yang ditampilkan oleh seorang manajer atau pimpinan, yaitu perencanaan, pengorganisasian, pemimpin dan pengawasan. Oleh karena itu, manajemen diartikan sebagai proses merencanakan, mengorganising, memimpin, dan mengendalikan upaya organisasi dengan segala aspeknya agar tujuan organisasi tercapai secara efektif dan efisien.

\section{Konsep Dana Desa}

Peraturan Pemerintah Nomor 60/2014 tentang Dana Desa yang bersumber dari APBN, Pasal 1, ayat 2 : Dana Desa adalah Dana yang bersumber dari APBN yang diperuntukkan bagi Desa yang ditransfer melalui APBD Kab/Kota dan digunakan untuk membiayai penyelenggaraan pemerintahan, pelaksanaan pembangunan, pembinaan kemasyarakatan, dan pemberdayaan masyarakat. Selanjutnya dalam pasal 6 disebutkan bahwa Dana Desa tersebut ditransfer melalui APBD kabupaten/kota untuk selanjutnya ditransfer ke APB Desa. 
Undang-Undang Nomer 6 Tahun 2014 tentang Desa menjadi tonggak perubahan paradigma pengaturan desa. Desa tidak lagi dianggap sebagai objek pembangunan, melainkan ditempatkan menjadi subjek dan ujung tombak pembangunan dan peningkatan kesejahteraan masyarakat. Desa diberikan kewenangan untuk mengatur dan mengurus urusan pemerintahan, kepentingan masyarakat setempat berdasarkan prakarsa masyarakat, hak asal usul, adat istiadat, dan nilai sosial budaya masyarakat desa yang pengaturannya berpedoman pada 13 azas.

Menurut PP No 43/2014 tentang Peraturan Pelaksanaan UU No. 6/2014 Tentang Desa, Dana Desa adalah dana yang bersumber dari anggaran pendapatan dan belanja negara yang diperuntukkan bagi Desa yang ditransfer melalui APBD kabupaten/kota dan digunakan Ketentuan mengenai Dana Desa yang bersumber dari APBN diatur dalam PP tersendiri, tetapi implementasi PP tersebut merupakan satu kesatuan.

Peraturan Pemerintah disusun dalam rangka mewujudkan penyelenggaraan Desa yang berasas penyelenggaraan pemerintahan yang baik serta sejalan dengan asas pengaturan Desa sebagaimana diamanatkan oleh UU No. 6/2014 tentang Desa, antara lain kepastian hukum, tertib penyelenggaraan pemerintahan, tertib kepentingan umum, keterbukaan, profesionalitas, akuntabilitas, efektivitas dan efisiensi, kearifan lokal, keberagaman serta partisipasi. Dalam melaksanakan pembangunan Desa, diutamakan nilai kebersamaan, kekeluargaan, dan kegotongroyongan guna mewujudkan perdamaian dan keadilan sosial. untuk membiayai penyelenggaraan pemerintahan, pelaksanaan pembangunan, pembinaan kemasyarakatan, dan pemberdayaan masyarakat.

Setiap tahapan proses pengelolaan keuangan desa, memiliki peraturan yang harus dipahami dan dilaksanakan sesuai dengan batasan waktu yang telah ditentukan. Kegiatan Pengelolaan Keuangan Desa dapat dilaksanakan dengan baik tentunya harus didukung adanya sumber daya manusia yang kompeten dan berkualitas serta sistem dan prosedur keuangan yang memadai. Maka selayaknya, pemerintah desa dituntut memiliki struktur organisasi pengelolaan keuangan, yang menjadi acuan dalam kegiatan pengelolaan keuangan desa.

\section{Konsep Efisiensi dan Efektifitas \\ Konsep Efisiensi}

Pemberian kewenangan diharapkan meningkatkan efisiensi, efektivitas, dan akuntabilitas sektor publik di Indonesia. Dengan otonomi, Daerah dituntut untuk mencari alternatif sumber pembiayaan pembangunan tanpa mengurangi harapan masih adanya bantuan dan bagian (sharing) dari Pemerintah Pusat dan menggunakan dana publik sesuai dengan prioritas dan aspirasi masyarakat. Efektivitas berasal dari kata efektif yang mengandung pengertian dicapainya tujuan yang telah ditetapkan. Efektivitas selalu terkait dengan hubungan antara hasil yang diharapkan dengan hasil yang sesungguhnya dicapai. Efektivitas dapat dilihat dari berbagai sudut pandang dan dapat dinilai dengan berbagai cara dan mempunyai kaitan yang erat dengan efisiensi.

Pengertian efisiensi menurut Halim (2001) adalah perbandingan antara output dengan input. Ukuran efisien dapat dikembangkan dengan menghubungkan antara biaya yang sesungguhnya dengan biaya standar yang telah ditetapkan sebelumnya (misalnya anggaran). Dari definisi tersebut maka Efisiensi adalah berbanding antara keluaran dan masukan.

\section{Pengukuran Effisiensi}

Pemberian otonomi daerah diharapkan dapat meningkatkan efisiensi, efektivitas, dan akuntabilitas sektor publik di Indonesia. Dengan otonomi, Daerah dituntut untuk mencari alternatif sumber pembiayaan pembangunan tanpa mengurangi harapan masih adanya bantuan dan bagian (sharing) dari Pemerintah Pusat dan menggunakan dana publik sesuai dengan prioritas 
dan aspirasi masyarakat. Menurut Handoko (1995) efisiensi adalah kemampuan untuk menyelesaikan suatu pekerjaan dengan benar. Ini merupakan perhitungan perbandingan antara keluaran (output) dan masukan (input).

Efisiensi penyelenggaraan pemerintahan daerah dapat dicapai dengan memperhatikan aspek hubungan dan tata kerja antar instansi pemerintah daerah dengan memanfaatkan potensi dan keanekaragaman suatu daerah. Efisiensi merupakan rasio antara biaya yang dikeluarkan untuk belanja kegiatan Pemdes Tegalarum Kabupaten Demak. Ukuran ini dipakai untuk memperoleh pendapatan tertentu digunakan seminimal mungkin sebagaimana motif ekonomi. Karena itu tingkat efisiensi yang terjadi akan lebih besar apabila biaya yang dikeluarkan untuk merealisasikan penerimaan ditekan serendah mungkin, sehingga realisasi penerimaan semakin meningkat, maka efisiensi untuk melihat upaya mengoptimalkan kombinasi penggunaan input, atau untuk menghasilkan tingkat output tertentu dengan jumlah ongkos yang minimum, atau kemampuan untuk menghasilkan output sebesar mungkin dari jumlah input tertentu.

\section{Konsep Effektifitas}

Efektivitas pada umumnya sering dihubungkan dengan efisiensi dalam pencapaian tujuan baik tujuan individu, kelompok dan organisasi. Menurut Gibson (1995) ada 2 (dua) pendekatan dalam menilai keefektifan menurut tujuan dan teori sistem. Berdasarkan pendekatan tujuan maka untuk merumuskan dan mengukur keefektifan melalui pencapaian tujuan ditetapkan dengan usaha kerjasama. Sedangkan pendekatan teori sistem menekankan pentingnya adaptasi terhadap tuntutan ekstern sebagai kriteria penilaian keefektifan. Lebih lanjut Gibson menyatakan bahwa konsep efektivitas organisasi haruslah mencerminkan 2 (dua) kriteria, yakni (a) keseluruhan siklus masukan-proses-keluaran, dan (b) mencerminkan hubungan timbal balik antara organisasi dan lingkungannya.

Efektivitas dalam pengertian yang umum menunjukkan pada taraf tercapainya hasil. efektivitas dari pemerintah daerah adalah bila tujuan pemerintah daerah tersebut dapat dicapai sesuai dengan kebutuhan yang direncanakan. Sesuai dengan Permendagri Nomor 13/2006 pasal 4 ayat 4, efektif adalah pencapaian hasil program dengan target yang telah ditetapkan, yaitu dengan cara membandingkan keluaran dengan hasil. Efektivitas berfokus pada outcome atau hasil. Suatu organisasi, program atau kegiatan dikatakan efektif apabila output yang dilaksanakan bisa memenuhi target yang diharapkan (Mahmudi: 2007). Pengertian efektivitas berhubungan dengan derajat keberhasilan suatu operasi pada sektor publik sehingga suatu kegiatan dikatakan efektif jika kegiatan tersebut mempunyai pengaruh besar terhadap kemampuan menyediakan pelayanan masyarakat yang merupakan sasaran yang telah ditetapkan sebelumnya.

Konsep efektivitas merupakan pernyataan secara menyeluruh tentang seberapa jauh suatu organisasi telah mencapai tujuannya. Efektivitas juga dapat berarti kegiatan yang selesai tepat pada waktunya sesuai rencana yang telah ditetapkan, jadi apabila suatu organisasi tersebut telah mencapai tujuannya telah berjalan dengan efektif. Dari pengertian tersebut dapat diambil kesimpulan bahwa efektivitas adalah perbandingan antara output (keluaran) dengan tujuan, sehingga untuk mengetahui efektivitas pengelolaan keuangan yaitu dengan membandingkan antara realisasi belanja dengan target belanja. 


\section{Ruang Lingkup Penelitian}

\section{METODE PENELITIAN}

Jenis Penelitian deskriptif, dengan Tujuan untuk menganalisis efektivitas dan efisiensi pengelolaan anggaran Dana Desa yang diprioritaskan untuk pembangunan dan pemberdayaan masyarakat Desa serta multiplier effect yang terjadi jika prioritas Dana Desa tersebut dialokasikan dengan benar. Penelitian ini menggunakan Metode Kombinasi (Mix Methods). Johnson dan Cristensen (2007) dalam Sugiyono (2017) memberikan definisi tentang penelitian kombinasi yaitu penelitian yang menggabungkan pendekatan kuantitatif dan kualitatif yang digunakan secara bersama-sama dalam suatu kegiatan penelitian, sehingga diperoleh data yang lebih komprehensif, valid, realibel dan objektif.

Pengambilan data dengan menggunakan model Sequential Explanatory Design. Metode penelitian model tersebut bercirikan dengan pengumpulan data dan analisis data kuantitatif pada tahap pertama, dan diikuti dengan pengumpulan dan analisi data kualitatif pada tahap kedua, guna memperkuat hasil penelitian kuantitatif yang dilakukan pada tahap pertama.

\section{Jenis dan Sumber Data}

Penelitian ini menggunakan dua jenis data yakni data sekunder dan data primer. Data sekunder yang merupakan data penelitian diperoleh dari sumber kedua atau sumber sekunder dari data yang dibutuhkan (Bungin, 2010) dan data primer yang merupakan data penelitian yang diperoleh dari sumber asli.

\section{Informan Penelitian}

Penelitian dengan menggunakan pendekatan metode kualitatif peranan informan sangat penting karena dari mereka data akan diperoleh. Secara teoritis Informan penelitian adalah orang yang di manfaatkan untuk memberikan informasi tentang situasi dan kondisi latar belakang penelitian dan merupakan orang yang benar-benar mengetahui permasalahan yang akan di teliti (Moleong 2015;163; Nasir, 2005).

Penentuan informan menggunakan teknik purposive sampling, sebagaimana maksud yang disampaikan oleh Sugiyono dalam buku Memahami Penelitian Kualitatif, Purposive sampling adalah teknik pengambilan sampel sumber data dengan pertimbangan tertentu. Pertim-bangan tertentu ini, misalnya orang tersebut yang dianggap paling tahu tentang apa yang kita harapkan, atau mungkin dia sebagai penguasa sehingga akan memudahkan peneliti menjelajahi obyek/situasi sosial yang diteliti." (Sugiyono, 2012:54). Pemilihan informan dalam penelitian ini, diperoleh dengan melakukan kegiatan wawancara yang dilakukan terhadap 6 informan. Dengan rincian pada tabel 3

Tabel 3 Informan Penelitian

\begin{tabular}{cllllc}
\hline No & \multicolumn{1}{c}{ Nama } & \multicolumn{1}{c}{$\begin{array}{c}\text { Jenis } \\
\text { Kelamin }\end{array}$} & \multicolumn{1}{c}{ Jabatan } & Informan & Jumlah \\
\hline 1 & H. Mashudi & Laki-Laki & Sekretaris Desa & Utama & 1 \\
2 & Hj. Murtini. SH & Perempuan & Kasie Pembangunan & Utama & 1 \\
3 & H. Moh. Samin. & Laki-Laki & Kepala BPD & Kunci & 1 \\
& M.Si & & & & 1 \\
4 & Uswatun Hasanah & Perempuan & Bendahara PKK & Pendukung & 1 \\
5 & Agil Wibowo & Laki-Laki & Ket. Karang Taruna & Pendukung & 1 \\
6 & Joni & Laki-Laki & Masyarakat Umum & Pendukung & 1 \\
& Jumlah & & & & 6 \\
\hline
\end{tabular}

Sumber: Penelitian 2020 


\section{Instrumen Penelitian}

Analisis data adalah proses mencari dan menyusun secara sistematis data yang diperoleh dari hasil wawancara, catatan lapangan, dan bahan-bahan lain, sehingga dapat mudah dipahami, dan temuannya dapat diinformasikan kepada orang lain, (Sugiyono, 2013). Dari penjelasan tersebut dapat dipahami bahwa data yang telah didapatkan di lapangan kemudian diolah sesuai dengan keperluan dari penelitian baik ditabulasi ataupun diberi kode sesuai kebutuhan.

Penulisan ini menggunakan dua variabel penelitian, yaitu efektifitas dan Efisiensi. Dengan demikian instrumen yang digunakan untuk mengumpulkan data kuantitatif yaitu efektivitas program Dana Desa yang melihat pada realisasi belaja dan target belanja, sedangkan Efisiensi anggaran melihat pada realisai belanja dan realisasi pendapatan.

Penelitian ini tidak hanya menggunakan intrumen kuantitatif, tetapi junga menggunakan instrumen kualitatif. Dalam penelitian kualitatif yang menjadi instrumen adalah peneliti sendiri. Dalam hal ini peneliti melakukan wawancara kepada sekretaris desa, ketua tim pelaksana pembangunan dan masyarakat, yang dan selanjutnya dilakukan analisis, memberi arti dan makna terhadap data yang ditemukan dan selanjutnya membuat kesimpulan.

\section{Metode Analisis Efisiensi}

Efisiensi menurut Permendagri No 13/2006, adalah hubungan antara masukan (input) dan keluaran (output), efisiensi merupakan ukuran apakah penggunaan barang dan jasa yang dibeli dan digunakan oleh organisasi perangkat pemerintahan untuk mencapai tujuan organisasi perangkat pemerintahan dapat mencapai manfaat tertentu yakni pendapatan bagi pemerintah. Sedangkan input merupakan segala sesuatu yang dibutuhkan agar pelaksanaan kegiatan dapat berjalan untuk menghasilkan keluaran yakni berupa belanja. Output adalah sesuatu yang diharapkan langsung dapat dicapai dari suatu kegiatan yang dapat berupa fisik dan non-fisik dalam hal ini adalah pendapatan.

Efisiensi merupakan rasio antara biaya yang dikeluarkan untuk belanja kegiatan Pemdes Tegalarum Kabupaten Demak. Ukuran ini dipakai untuk memperoleh pendapatan tertentu digunakan seminimal mungkin sebagaimana motif ekonomi. Karena itu tingkat efisiensi yang terjadi akan lebih besar apabila biaya yang dikeluarkan untuk merealisasikan penerimaan ditekan serendah mungkin, sehingga realisasi penerimaan semakin meningkat, maka efisiensi untuk melihat upaya mengoptimalkan kombinasi penggunaan input, atau untuk menghasilkan tingkat output tertentu dengan jumlah ongkos yang minimum, atau kemampuan untuk menghasilkan output sebesar mungkin dari jumlah input tertentu.

Efisiensi merupakan perbandingan antara output dengan input atau dengan istilah lain output/unit input (Mahmudi, 2007). Dengan demikian Efisiensi atau daya guna adalah perbandingan antara output dengan input. Output merupakan realisasi biaya untuk memperoleh penerimaan daerah dalam hal ini adalah belanja dan input merupakan realisasi dari penerimaan daerah dalam hal ini adalah pendapatan. Untuk menganalisis tingkat efisiensi dalam pengelolaan keuangan dengan melihat perbandingan antara realisasi anggaran belanja dengan realisasi anggaran pendapatan sebagai berikut:

$$
\text { Efisiensi }=\frac{\text { Output }(\text { Rasio Belanja })}{\text { Input }(\text { Realisasi Pendapatan })} \times 100 \%
$$




\section{Metode Analisis Efektifitas}

Menurut Ravianto dalam Masruri (2014:11): "Efektifitas adalah seberapa baik pekerjaan yang dilakukan, sejauh mana orang menghasilkan keluaran sesuai dengan yang diharapkan. Ini berarti bahwa apabila suatu pekerjaan dapat diselesaikan dengan perencanaan, baik dalam waktu, biaya mau pun mutunya, maka dapat dikatakan efektif." Menurut pendapat Mahmudi dalam bukunya Manajemen Kinerja Sektor Publik mendefinisikan Efektifitas, sebagai berikut: "Efektifitas merupakan hubungan antara output dengan tujuan, semakin besar kontribusi (sumbangan) output terhadap pencapaian tujuan, maka semakin efektif organisasi, program atau kegiatan" (Mahmudi, 2005:92).

Output dalam hal ini adalah realisasi belanja sedangkan tujuan atau target adalah target belanja. Makin besar kontribusi output terhadap tujuan makin efektiflah satu unit tersebut. Dengan demikian untuk menganalisis efektivitas Pengelolaan Keuangan dapat dilihat dari perbandingan antara realisasi belanja dengan target belanja sebagai berikut:

$$
\text { Efektifitas }=\frac{\text { Output (Rasio Belanja) }}{\text { Input (Realisasi Pendapatan })} \times 100 \%
$$

\section{HASIL DAN PEMBAHASAN}

\section{Analisis data}

Berdasarkan fokus penulisan akan disajikan analisis kuantitatif (Rasio Effisiensi dan Rasio Efektifitas) dan analisis Kualitatif dengan menggunakan pendekatan wawancara kepada informan yang telah dipilih serta data yang telah didapatkan dari berbagai sumber.

\section{Analisis Pengelolaan Dana Desa}

Berikut disampaikan data penerimaan dana desa yang diterima oleh pemerintah desa Tegalarum pada Tahun Anggaran 2016-2020 dari pemerintah pusat seperti pada Tabel 4

Tabel 4 Penerimaan Dana Desa Pemerintah Desa Tegalarum Tahun 2016-2020 (Rupiah)

\begin{tabular}{lrrrrr}
\hline \multirow{2}{*}{ Tahun } & Alokasi Dana & \multicolumn{3}{c}{ Penerimaan } & Peraturan \\
\cline { 3 - 5 } & Desa & Tahap I & Tahap II & Tahap III & Bupati No \\
\hline 2016 & 689.881 .000 & 413.928 .600 & 275.952 .400 & - & $27 / 2016$ \\
2017 & $880,443,000$ & $528,265,800$ & $352,177,200$ & - & $08 / 2017$ \\
2018 & $1,012,825,000$ & $202,565,000$ & $405,130,000$ & $405,130,000$ & $09 / 2018$ \\
2019 & 1.016 .591 .000 & 203.318 .200 & 406.636 .400 & 406.636 .400 & $02 / 2019$ \\
2020 & 1.058 .909 .000 & 427.886 .400 & 423.563 .600 & 207.459 .000 & $05 / 2020$ \\
Jumlah & $\mathbf{4 . 6 5 8 . 6 4 9 . 0 0 0}$ & $\mathbf{1 . 7 7 5 . 9 6 4 . 0 0 0}$ & $\mathbf{1 . 8 6 3 . 4 5 9 . 6 0 0}$ & $\mathbf{1 . 0 1 9 . 2 2 5 . 4 0 0}$ & \\
\hline
\end{tabular}

Sumber : Perbup 2016-2020 di olah untuk Penelitian (2020)

Pada Tabel 4 terlihat adanya perubahan skema dan kebijakan yang diambil oleh pemerintah dengan tujuan untuk meningkatkan pembangunan dan kesejahteraan masyarakat. Dengan meningkatnya pembangunan dan kesejahteraan dapat di indikatori dengan keterlibatan dan peran aktif masyarakat dan dirasakan wujudnya oleh masyarakat. Pembangunan yang dilakukan oleh pemerintahan desa dilakukan secara fisik dan non fisik. Adapun realisasi belanja yang telah dilakukan oleh Pemerintah Desa Tegalarum, seperti pada tabel 5 
Tabel 5 Realisasi Belanja Desa Pada Desa Tegalarum Tahun 2016-2020

\begin{tabular}{ccrr}
\hline \multirow{2}{*}{ Tahun } & Kegiatan & Pengeluaran & Prosentase \\
& $(\mathrm{Rp})$ & $(\%)$ \\
\hline \multirow{2}{*}{2016} & Pembangunan Desa & 633.911 .000 & 91,89 \\
& Pemberdayaan Masyarakat & 55.970 .000 & 8,11 \\
& Jumlah & $\mathbf{6 8 9 . 8 8 1 . 0 0 0}$ & $\mathbf{1 0 0}$ \\
2017 & Pembangunan Desa & 836.842 .250 & 94,73 \\
& Pemberdayaan Masyarakat & 46.600 .750 & 5,27 \\
& Jumlah & $\mathbf{8 8 3 . 4 4 3 . 0 0 0}$ & $\mathbf{1 0 0}$ \\
2018 & Pembangunan Desa & 929.803 .500 & 91,80 \\
& Pemberdayaan Masyarakat & 83.021 .500 & 8,20 \\
& Jumlah & $\mathbf{1 . 0 1 2 . 8 2 5 . 0 0 0}$ & $\mathbf{1 0 0}$ \\
2019 & Pembangunan Desa & 1.007 .142 .661 & 99,07 \\
& Pemberdayaan Masyarakat & 9.448 .339 & 0,93 \\
& Jumlah & $\mathbf{1 . 0 1 6 . 5 9 1 . 0 0 0}$ & $\mathbf{1 0 0}$ \\
& Pembangunan Desa & 427.148 .327 & 49,45 \\
& Pemberdayaan Masyarakat & 2.500 .000 & 0,29 \\
& Penanganan Keadaan Darurat & 434.140 .107 & 50,26 \\
& Jumlah & $\mathbf{8 6 3 . 7 8 8 . 4 3 4}$ & $\mathbf{1 0 0}$ \\
\hline & sumber : Data Penelitian di olah $\mathbf{( 2 0 2 1 )}$ &
\end{tabular}

Pada tabel 5 merupakan realisasi pengelolaan dan penggunaan Dana Desa yang digunakan untuk membiayai berbagai program pembangunan sehingga masyarakat dapat meningkat derajat kesejahteraannya karena pembangunan yang dilakukan merupakan usulan dan kebutuhan masyarakat sehingga masing-masing desa memiliki standar kecukupannya sendiri, yang telah ditetapkan dalam proses musyawarah desa berdasarkan ketentuan perundang-undangan yang berlaku, tanpa meninggalkan kearifan local masyarakat.

\section{Analisis Kuantatif}

Pada analisis data kuantitatif digunakan metode rasio perbandingan, dengan tujuan untuk membandingkan antara harapan dan realisasi, yang diukur dengan prosentanse semakin tinggi prosentase tersebut, berarti penggunaan dana desa semakin bisa dipertanggungjawabkan. Ukuran yang digunakan menggunakan rasio efisiensi dan efiktifitas yang di atur oleh Permenkeu RI.

\section{Analisis Efisiensi}

Analisis efisiensi melihat rasio perbandingan antara output dan input atau realisasi belanja dengan realisasi pendapatan Desa dalam hal ini yaitu Dana Desa. Semakin kecil rasio ini maka semakin efisien, begitu juga sebaliknya. Jika diasumsikan bahwa pengeluaran yang dibelanjakan sesuai dengan apa yang dibutuhkan masyarakat atau apa yang yang menjadi program desa, dan memenuhi apa yang direncanakan.

Penyaluran dana desa disetiap Desa memiliki besaran anggaran yang berbeda-beda karena pemerintah memperhitungan jumlah penduduk, angka kemiskinan, luas wilayah dan kesulitan geografis setiap Desa. Dalam mengukur Efisiensi lebih menitik beratkan pada kemampuan suatu organisasi untuk mencapai tujuan yang diharapkan dengan penggunaan sumber daya yang lebih hemat. Pada tabel 6 memperlihatkan tingkat effisiensi penggunaan dana desa oleh pemerintah desa Tegalarum. 
Tabel 6 Tingkat Efisiensi Pengelolaan Dana Desa di Desa Tegalarum

\begin{tabular}{ccrcc}
\hline Tahun & $\begin{array}{c}\text { Realisasi } \\
\text { Belanja }\end{array}$ & $\begin{array}{c}\text { Realisasi } \\
\text { Pendapatan }\end{array}$ & Efisiensi & Kategori \\
\hline 2016 & 689.881 .000 & 689.881 .000 & 100,00 & Sangat Efisien \\
2017 & 880.443 .000 & 880.443 .000 & 100,00 & Sangat Efisien \\
2018 & 1.012 .825 .000 & 1.012 .825 .000 & 100,00 & Sangat Efisien \\
2019 & 1.015 .312 .661 & 1.016 .591 .000 & 99,87 & Efisien \\
2020 & 853.788 .434 & 1.058 .909 .000 & 80,63 & Cukup Efisien \\
Jumlah & $\mathbf{4 . 4 5 2 . 2 5 0 . 0 9 5}$ & $\mathbf{4 . 6 5 8 . 6 4 9 . 0 0 0}$ & $\mathbf{9 5 , 5 7}$ & Efisien \\
\hline
\end{tabular}

Sumber : Data Penelitian di Olah 2020

Dari hasil perhitungan pada tabel 6, menunjukan bahwa penggunaan dana desa yang dilakukan oleh aparatur pemerintah dan masyarakat Desa Tegalarum Kabupaten Demak Tahun 2016-2020, dikategorikan efektif. Hal ini, menandakan bahwa yang diharapkan oleh seluruh stakeholder Desa Tegalarum telah sesuai dengan yang direncanakan. Apa yang telah dilakukan dalam pengelolaan dana desa telah sesuai dengan Asas-asas Pengelolaan Keuangan Desa sebagaimana tertuang dalam Permendagri Nomor 113/2014 yaitu transparan, akuntabel, partisipatif serta dilakukan dengan tertib dan disiplin anggaran. Hasil penelitian ini memperkuat hasil penelitian yang dilakukan oleh Moeljono dan Williyanto (2019). Juga dengan teori yang disampaikan oleh Halim (2001), yang menyatakan bahwa efisiensi perbandingan antara output dengan input. Ukuran efisien dapat dikembangkan dengan menghubungkan antara biaya yang sesungguhnya dengan biaya standar yang telah ditetapkan sebelumnya (misalnya anggaran). Dari definisi tersebut maka Efisiensi adalah berbanding antara keluaran dan masukan.

Sedangkan ditahun 2020 penggunaan anggaran baru digunakan sebesar 80,63\%, hal ini dikarenakan bahwa data diambil bulan September sedangankan tahun anggaran adalah 1 Januari sampai dengan tanggal 31 Desember 2020, jadi masih ada kegiatan yang belum terealisasikan. Tekanan Efisiensi lebih menitik beratkan pada kemampuan suatu organisasi untuk mencapai tujuan yang diharapkan dengan penggunaan sumber daya yang lebih hemat. Kategori efisien yang telah dijelaskan membuat kesimpulan jika penggunaan anggaran Dana Desa masih dikatakan hemat. Suatu kerja organisasi dikatakan efisien apabila mencapai keluaran yang lebih tinggi berupa hasil, produktivitas, performance dibanding masukan-masukan yang berupa tenaga kerja, bahan, uang, mesin dan waktu yang digunakan. Manfaat efisiensi yang dirasakan masyarakat adalah pada sector pelayanan, jika masyarakat telah memperoleh hasil yang diinginkan dengan biaya paling minimal. Biaya yang disebutkan adalah waktu, tenaga atau bahkan uang.

Kategori cukup efisien pada data diatas menunjukan bahwa hasil produktivitas aparatur desa tidak lebih tinggi dari tenaga kerja, uang serta waktu yang dikeluarkan. Contohnya belum selesainya penggunaan tahun anggaran.

\section{Analisis Effiktifitas}

Efektifitas yaitu ukuran yang menyatakan seberapa jauh target (kuantitas, kualitas, dan waktu yang telah tercapai. Dimana semakin besar presentase target yang dicapai, makin tinggi efektivitasnya. Indikator efektivitas adalah rasio antara realisasi pengunaan Dana Desa dengan target belanja Dana Desa. Berikut Pengukuran Efektifitas. 
Tabel 7 Tingkat Efektifitas Pengelolaan Dana Desa di Desa Tegalarum

\begin{tabular}{ccccc}
\hline Tahun & $\begin{array}{c}\text { Realisasi } \\
\text { Belanja }\end{array}$ & $\begin{array}{c}\text { Target } \\
\text { Belanja }\end{array}$ & $\begin{array}{c}\text { Efektifitas } \\
\mathbf{\%}\end{array}$ & Kategori \\
\hline 2016 & 689.881 .000 & 689.881 .000 & 100,00 & Sangat Efektif \\
2017 & 880.443 .000 & 880.443 .000 & 100,00 & Sangat Efektif \\
2018 & 1.012 .825 .000 & 1.012 .825 .000 & 100,00 & Sangat Efektif \\
2019 & 1.015 .312 .661 & 1.015 .312 .661 & 100,00 & Sangat Efektif \\
2020 & 853.788 .434 & 1.058 .909 .000 & 80,63 & Cukup Efektif \\
Jumlah & $\mathbf{4 . 4 5 2 . 2 5 0 . 0 9 5}$ & $\mathbf{4 . 6 5 7 . 3 7 0 . 6 6 1}$ & $\mathbf{9 5 , 6 0}$ & Efektif \\
\hline
\end{tabular}

Sumber: Data Penelitian di olah 2020

Tingkat efektivitas dipengaruhi oleh keberhasilan pemerintahan Desa dalam mengelola pendapatan Dana Desa dan memaksimalkan kebutuhan yang dibutuhkan masyarakat. Manfaat analisis efektivitas pengolaan Dana Desa bagi masyarakat adalah sebagai tolak ukur tentang penyediaan pelayanan yang disediakan oleh aparatur Desa. Kategori efektif dapat berubah setiap tahunnya. Tujuan adanya Dana Desa adalah meningkatkan kesejahteraan warga Desa.

\section{Analisis Kualitatif}

Pada analisis kualitatif, penulis melakukan wawancara dengan aparatur desa Tegalarum sebagai salah satu dari tim pelaksana dan pengelola Dana Desa, sekaligus selaku Sekretaris Desa Tegalarum, Kabupatem Demak. Berikut pernyataan dari Bapak H. Mashudi :

"Dana desa sudah diatur dan dijelaskan di Peraturan Bupati (Perbup) Demak, diperaturan, disebutkan berbagai aturan dan formula berapa alokasi yang diterima dan yang pasti tiap tahun terus mengalami kenaikan walaupun kenaikannya sedikit sekali, tidak sesuai dengan harapan, namun desa masih bisa membangun dan membiayai operasional pemerintahan Desa".

pernyataan tersebut diperkuat informan selanjutnya yaitu Bapak H. Moh. Samin. M.Si selaku Kepala BPD Desa Tegalarum, Kabupaten Demak, berikut hasil pernyatannya.

“Dana Desa tidak turun dari langit, desa harus melengkapi syarat-syarat untuk pengajuan dan pencairan DD diantaranya adalah Peraturan Desa dan APBDesa. Setelah persyaratan tersebut telah dipenuhi oleh desa maka uang dari RKUD akan langsung masuk di rekening kas desa, kemudian ada proses namanya musyawarah desa untuk menentukan penggunaan dana desa, di desa itu ada 3 dokumen yaitu RPJMDes dibuat oleh kepala desa dalam jangka waktu 6 tahunan, RKP yang disusun tiap tahun yaitu berisi penjabaran dari RPJMDesa, setelah itu RPJMDesa dan RKP ini menjadi acuan dalam penyusunan APBDes yang dikerjakan tiap tahun berjalan"

Pemerintah Desa Tegalarum dalam waktu 5 tahun sejak tahun 2016-2020 telah menerima transfer Dana Desa dari Pemerintah Pusat melalui pemerintah kabupaten Demak, adapun jumlah dana desa yang diterima Desa Tegalarum adalah sebagai berikut:

Tabel 8 Penerimaan Dana Desa Pemerintah Desa Tegalarum Tahun 20162020

\begin{tabular}{cccc}
\hline Tahun & Dasar Hukum & $\begin{array}{c}\text { Total Dana Desa } \\
\text { (Rupiah) }\end{array}$ & $\begin{array}{c}\text { Kenaikan } \\
(\mathbf{\%})\end{array}$ \\
\hline 2016 & Perbup No. 27/2016 & 689.881 .000 & 0,44 \\
2017 & Perbup No. 08/2017 & 880.443 .000 & 0,47 \\
2018 & Perbup No. 09/2018 & 1.012 .825 .000 & 0,50 \\
2019 & Perbup No. 02/2019 & 1.016 .591 .000 & 0,49 \\
2020 & Perbup No. 05/2020 & 1.058 .909 .000 & - \\
Jumlah & & $\mathbf{4 . 6 5 8 . 6 4 9 . 0 0 0}$ & \\
\hline
\end{tabular}

Sumber : Perbup 2016-2020 di olah untuk Penelitian (2020) 
Pernyataan dari kedua informan tentang naiknya perolehan Dana Desa setiap tahun terbukti benar, hal ini terlihat pada tabel 8. pada tabel tersebut jelas kenaikannya, walaupun prosentase kenaikan tidak sampai $1 \%$. Kenaikan tertinggi terjadi pada tahun 2018 yakni sebesar $0.50 \%$.

Penulis kembali melakukan penggalian data hal ini berkaitan dengan tingkat effektifitas dan effisiensi pengelolaan dana desa dalam meningkatkan pembangunan infrastruktur dan Pemberdayaan Masyarakat, berikut pernyataan dari informan tersebut:

"Pemerintah mengambil kebijakan, dengan tujuan untuk meningkatkan kehidupan warga desa. Apalagi tidak bisa dipungkiri warga desa itu tingkat perekonomiannya menengah kebawah.”.

Apa yang disampaikan oleh informan menunjukan bahwa adanya dana desa dapat membantu dan mempercepat proses pembangunan di pedesaan sehingga kesenjangan antar wilayah dapat diminimalisir. Pada kesempatan lain penulis melakukan wawancara dengan sekretaris desa dan kepala seksi pembangunan desa Tegalarum tentang regulasi dan aturan tentang dana desa dan pengelolaannya di desa Tegalarum. berikut pernyataan dari informan (H. Mashudi):

"Regulasi Pengelolaan Dana Desa cukup bagus walaupun banyak aturan yakni dari pemerintah dan DPR yang wujudnya UU, terus dari Departemen Teknis yakni kementerian Dalam Negeri, Kementerian Desa dan Kementerian Keuangan.

Selain itu penulis juga melakukan wawancara kepada masyarakat yang juga berperan dalam kegiatan desa terkait dengan keterlibatannya dalam proses perencanaan Dana Desa, yaitu ketua karang taruna dan bendahara PKK. Berikut penjelasan dari ketua karangtaruna periode 20162020 mengenai keterlibatannya dalam proses perencanaan Dana Desa :

"Kalau saya selalu diundang mas, tapi ya lihat-lihat dulu soalnya saya juga punya anak kecil, kalau si kecil tidak rewel ya saya ikut, jadi saya sering terlambat pas datang pas sudah ada keputusan, jadi saya tinggal ikut saja"

demikian juga pernyataan dari ketua Karang Taruna

"Saya selalu diundang dalam kegiatan Musyawarah Desa, dalam pelaksanaannya masyarakat selalu menyampaikan pendapat tentang kegiatan-kegiatan yang akan direncanakan, namun tidak semua dapat di realisasikan karena terbatasnya dana tapi usulan di catat dan di ajukan Kembali pada waktu mendatang”

Dari hasil wawancara yang disampaikan oleh ketua karang taruna dan bendahara PKK, dapat dikatakan bahwa perencanaan kegiatan Dana Desa sudah melibatkan masyarakat, dan masyarakat sudah mengetahui bahwa proses perencanaan yang dilakukan harus sesuai dengan RPJMDes dan RKP.

Pernyataan dari Ketua Karang Taruna dan Bendahara PKK desa Tegalarum dilakukan uji Trigulasi dengan masyarakat desa Tegalarum, namun masyarakat tersebut bukan merupakan penduduk asli namun pendatang. Berikut penulis sajikan hasil perencanaan kegiatan dana desa, dengan melakukan wawancara dengan masyarakat biasa yang tidak mempunyai jabatan di dalam masyarakat, dia adalah Bapak Joni Usia 34 tahun dan merupakan pendatang di desa Tegalarum, namun sudah bermukim selama 10 tahun jadi menurut hemat penulis beliau layak di jadikan informan. berikut pernyatan beliau:

"kalau saya program utama ya bangun jalan dengan cara betonisasi diseluruh desa, hal ini sesuai dengan usulan warga, karena ada beberapa wilayah yang Jalannya masih tanah, kalau hujan ya blethok dan mathol sehingga menganggu aktifitas warga Jalan merupakan factor utama untuk aktifitas warga, anda tahu sendiri kalau banyak penduduk disini yang bekerja di Semarang, kalua jalannya blethok dan mathol mereka akan malas dalam melakukanm aktifitas sehingga 
akan menganggu dapur mereka. Coba apakah anda mau naik montor di jalan yang mbletok dan mathol

Berdasarkan wawancara dengan mayarakat umum, penulis melakukan penggalian lebih lanjut dimana penggalian data di fokuskan pada proses perencanaan dan implementasi yang melibatkan peran serta masyarakat, berikut pernyataan dari Kasie Pembangunan Hj. Murtini. SH :

Rencana Kerja Pembangunan Desa (RKPDes) dalam pengelolaan Dana Desa di bidang pembangunan fisik ada 3 program yaitu pembangunan betonisasi jalan desa, pembuatan sabuk irigasi dan pembangunan gapura desa. Sedangkan di bidang Pembangunan non fisik ada 5 program yaitu pelatihan kepala Desa dan perangkat, peningkatan kapasitas lembaga masyarakat, pembinaan pemuda dan olahraga, pembinaan organisasi PKK dan pemberdayaan lansia.

Untuk melihat kesesuaian yang telah disampaikan oleh Informan berikut disajikan alokasi anggaran yang telah di releasikan pada tahun 2018, dimana penyerapan sangat efektif. Adapun realisasi penggunan dana desa tersebut pada tabel 9.

Tabel 9 Anggaran Dana Desa Pada Desa Tegal Arum, Kabupaten Demak Tahun 2018

\begin{tabular}{llcr}
\hline No & \multicolumn{1}{c}{ Nama Kegiatan } & $\begin{array}{c}\text { Alokasi } \\
(\mathbf{\%})\end{array}$ & $\begin{array}{c}\text { Jumlah } \\
(\mathbf{R p})\end{array}$ \\
\hline 1 & Penyelenggaraan Pemerintahan Desa & $20 \%$ & 202.565 .000 \\
2 & Pelaksanaan Pembangunan Desa & $64 \%$ & 648.208 .000 \\
3 & Pemberdayaan Masyarakat & $10 \%$ & 101.282 .500 \\
4 & Pembinaan Masyarakat & $5 \%$ & 50.641 .250 \\
5 & Dana Cadangan & $1 \%$ & 10.128 .250 \\
& Jumlah & $\mathbf{1 0 0} \%$ & $\mathbf{1 . 0 1 2 . 8 2 5 . 0 0 0}$ \\
\hline
\end{tabular}

Sumber : RKPDes Tegal Arum (2019)

Pada Tabel 9 terlihat bahwa alokasi terbesar digunakan untuk pembangunan fisik sebesar Rp 648.208.000 atau sebesar 64\% dari total Dana Desa, hal ini dimaksudkan bahwa pembangunan yang dilakukan oleh pemerintah desa dapat mendatangkan dampak positif bagi pembangunan dan perekonomian masyarakat, karena sebagaian besar dana di belanjakan secara langsung oleh pemerintah.

\section{KESIMPULAN DAN SARAN}

Proses Pengelolaan Dana Desa pada Desa Tegalarum Kabupaten Demak, dapat ditarik kesimpulan antara lain: 1) Penelitian dengan menggunakan pendekatan Kuantitatif didapatkan hasil : a) Hasil perhitungan Efisiensi, Secara akumulatif pelaksanaan pengelolaan anggaran dana desa dari tahun 2016-2020 dikategorikan efisien, dengan rentang nilai 95,57. b) Hasil perhitungan Efektifitas. Secara akumulatif pelaksanaan pengelolaan anggaran dana desa dari tahun 2016-2020 dikategorikan efektif, dengan rentang nilai 95,60.2) Penelitian dengan menggunakan pendekatan Kualitatif didapatkan hasil bahwa Peran aparatur pemerintahan aparat desa serta dukungan dari seluruh elemen masyarakat, mampu mengiplementasikan pengelolaan dana desa sesuai dengan kaidah perundang-undangan dan mengedepankan kebutuhan masyarakat. Hal ini, mampu meningkatkan layanan dan kesejahteraan masyarakat.

Berdasarkan uraian kesimpulan maka saran yang diajukan dalam penelitian ini adalah sebagai berikut: 1) Pemerintah Desa Tegalarum, dalam proses Pengelolaan Dana Desa telah melibatkan seluruh lapisan masyarakat sehingga tingkat efisiensi dapat dicapai dan perlu dipertahankan di masa datang. 2) Peran dan dukungan seluruh masyarakat, mampu mengiplementasikan 
pengelolaan dana desa sesuai dengan peraturan dan kebutuhan masyarakat. Kontribusi seluruh elemen lapisan masyarakat mampu meningkatkan pelayanan yang optimal dimasyarakat.

\section{DAFTAR PUSTAKA}

Adisasmita, S.A. 2011. Perencanaan Infrastruktur Transportasi Wilayah. Yogyakarta: Graha Ilmu.

Bungin Burhan. 2010. Metodologi Penelitian Kualitatif. PT Raja Grafindo Persada. Jakarta.

Darson. 2018. Efektivitas Pengelolaan Alokasi Dana Desa Dalam Meningkatkan Pelaksanaan Pembangunan ( Studi Kasus Pada Desa Pola Kecamatan Pasir Putih Kabupaten Muna). Jurusan Ilmu Administrasi Publik Fakultas Ilmu Administrasi Universitas Halu Oleo. Kendari

Gibson. James L. et.al, 1995. Organisasi dan Manajemen. Perilaku Struktur Proses, Alih Bahasa: Wahid, Djoerban. Jakarta. Erlangga.

Gie.The Liang, 2002, Administrasi Perkantoran Moderen. Yogyakarta: Liberty

Halim, Abdul. 2004. Manajemen Keuangan Daerah, Edisi Revisi, Yogyakarta: UPP AMP.

Hargono, DS. 2010. Efektifitas Penyaluran Alokasi Dana Desa Pada Empat Desa di Kabupaten Karangasem Propinsi Bali.

https://www.bps.go.id/pressrelease/2019/07/15/1629/persentase-penduduk-miskin-maret-

2019-sebesar-9-41-persen.html di akses tanggal 22 Juni 2020 Jam 1:17

Hudiyanto. 2005, Ekonomi Politik, Bumi Aksara, Jakarta

James L.Gibson, et.al, 1995. Organisasi dan Manajemen. Perilaku Struktur Proses, Alih Bahasa: Wahid, Djoerban, Jakarta: Erlangga.

Kenneth E. Boulding. 1970. A Primer on Social Dynamics: History as Dialectics and Development. The Free Press. New York

Kepmendagri Nomor No.690.900-327 Tahun 1996 Tentang Kriteria Penilaian Dan Kinerja Keuangan

Mahfud. 2009. "Analisis dampak alokasi dana desa (ADD) terhadap pemberdayaan masyarakat dan kelembagaan desa". Jurnal Organisasi dan Manajemen, Volume 5, Nomor 1, Maret 2009.

Moeljono, Moeljono dan Kusumo, Willyanto Kartiko. 2019. Efektivitas Pengelolaan Alokasi Dana Desa (Studi Kasus Pada Desa Tegal Arum Kecamatan Mranggen Kabupaten Demak). Majalah Ilmiah Solusi Vol. 17, No. 3 Juli 2019. http://iournals.usm.ac.id/index.php/solusi/article/view/1629.

Moleong, Lexy J.2015.Metode Penelitian Kualitatif.Bandung:Remaja Rosdakarya

Nanang Fattah. 2004. Konsep Manajemen Berbasis Sekolah (MBS) dan Dewan Sekolah, Bandung: Pustaka Bani Quraisy.

Nasir. 2005. Metode Penelitian. Bogor. Ghalia Indonesia.

Nurul Zuriah. 2009. Metodologi Penelitian Sosial dan Pendidikan. Jakarta. Bumi Aksara.

Novita, Dian. 2016. Analisis Efisiensi Dan Efektivitas Pengelolaan Anggaran Dana Desa Tahun 2015 Di Kecamatan Leuwiliang Kabupaten Bogor Provinsi Jawa Barat. Skripsi. Jurusan Ilmu Ekonomi dan Studi Pembangunan Fakultas Ekonomi Dan Bisnis Universitas Islam Negeri Syarif Hidayatullah. Jakarta.

Pahlevi. Indra. 2015. Dana Desa dan Permasalahannya. Pusat Pengkajian, Pengolahan Data dan Informasi (P3DI) Sekretariat Jenderal DPR RI. ISSN 2088-2351. www.dpr.go.id 
Peraturan Bupati Demak Nomor 2 Tahun 2019 Tentang Tata Cara Pembagian, Penetapan Rincian Dan Penggunaan Dana Desa Di Kabupaten Demak Tahun Anggaran 2019.

Peraturan Bupati Demak Nomor 2 Tahun 2020 Tentang Tata Cara Pembagian, Penetapan Rincian Dan Penggunaan Dana Desa Di Kabupaten Demak Tahun Anggaran 2020.

Peraturan Bupati Demak Nomor 8 Tahun 2016 Tentang Tata Cara Pembagian, Penetapan Rincian Dan Penggunaan Dana Desa Di Kabupaten Demak Tahun Anggaran 2016

Peraturan Bupati Demak Nomor 8 Tahun 2017 Tentang Tata Cara Pembagian, Penetapan Rincian Dan Penggunaan Dana Desa Di Kabupaten Demak Tahun Anggaran 2017

Peraturan Bupati Demak Nomor 9 Tahun 2018. Tata Cara Pembagian, Penetapan Rincian Dan Penggunaan Dana Desa Di Kabupaten Demak Tahun Anggaran 2018

Peraturan Menteri Dalam Negeri Nomor 113 Tahun 2014 Tentang Pengelolaan Keuangan Desa. Peraturan Menteri Desa, Pembangunan Daerah Tertinggal, Dan Transmigrasi Nomor 5 Tahun 2015 Tentang Penetapan Prioritas Penggunaan Dana Desa Tahun 2015

Peraturan Menteri Keuangan Republik Indonesia Nomor 93/PMK.07/2015 Tentang Tata Cara Pengalokasian, Penyaluran, Penggunaan, Pemantauan, dan Evaluasi Dana Desa.

Peraturan Pemerintah Nomor 43 tahun 2014 tentang Peraturan Pelaksanaan Undang-Undang Nomor Tahun 2014 Tentang Desa

Peraturan Pemerintah Nomor 60 Tahun 2014 tentang Dana Desa

Peraturan Pemerintah Republik Indonesia Nomor 22 Tahun 2015 Tentang Perubahan Atas Peraturan Pemerintah Nomor 60 Tahun 2014 Tentang Dana Desa Yang Bersumber Dari Anggaran Pendapatan Dan Belanja Negara.

Qalyubi Shyhabuddin. 2007. Manejemen Penelitian. Jakarta.

Raharjo, Try, Sjamsiar Sjamsuddin, Imam Hardjanto. 2013. Implementasi Kebijakan Alokasi Dana Desa (ADD) Tahun 2011 Di Desa Jembul Dan Desa Sumengko Kecamatan Jatirejo Kabupaten Mojokerto. Jurnal Wacana Vol.16, No.1. Universitas Brawijaya. Pemerintah Kabupaten Mojokerto.

Repbulik Indonesia, Undang-Undang Nomer 32 Tahun 2004 tentang Pemerintahan Daerah Repbulik Indonesia. Undang-Undang Nomer 06 Tahun 2014 Tentang Desa

Richard M Steers. 1997. Efektivitas Organisasi, diterjemahkan oleh Magdalena Jamin. Jakarta. Erlangga.

Santoso, Eko. 2011. Efisiensi dan Efektivitas Pengelolaan Keuangan Daerah di Kabupaten Ngawi. Tesis. Universitas Sebelas Maret. Surakarta.

Setyo Budi, Daniel. 2010. Efisiensi Relatif. Universitas Indonesia

Setyowati, Endang. 2011. Analisis Efisiensi Dan Efektivitas Pengeluaran Anggaran Belanja Langsung Barang Dan Jasa Pada Dinas Pengelola Keuangan Daerah Kabupaten Lumajang. Tesis. Universitas Jember.

Sugiyono. 2012. Memahami Penelitian Kualitatif. Alfabeta. Bandung

Sugiyono. 2017. Metode Penelitian Kombinasi (Mixed Methods). Bandung: Alfabeta.

Sulastri. Nova. 2016. Efektivitas Pengelolaan Alokasi Dana Desa (ADD) dalam Meningkatkan Pembangunan Fisik Desa Lakapodo Kecamatan Watopute Kabupaten Muna. Skripsi. Jurusan Ilmu Ekonomi. Fakultas Ekonomi Dan Bisnis Universitas Halu Oleo. Kendari Wibowo, 2016. Manajemen Kinerja, Edisi Kelima. Jakarta. PT. Raja Grafindo Persada 
SOLUSI : Jurnal Ilmiah Bidang Ilmu Ekonomi Vol. 19, No.2, bulan April tahun 2021, Hal 49-64 